\title{
BUSINESS ETHICS AND SOCIAL RESPONSIBILITY
}

\author{
N. Marinova \\ Department of Business Administration, New Bulgarian University, Sofia, Bulgaria
}

\begin{abstract}
There is still no universal approach to marketing ethics. However, it is an important factor in encouraging marketing decisions that are acceptable to the company as well as being beneficial to society. Social responsibility in marketing refers to the organization's duty to maximize its positive influence and minimize the negative impact on society. Because if ethics refers to moral values that guide decision-making by individuals, social responsibility affects the influence of the organization's decisions and society in general.
\end{abstract}

Key words: approaches, principles, standards, society, utilitarianism, ethical formalism, advertising, communication process;

\section{INTRODUCTION}

Marketing ethics is one of the most important for a marketing solution, but at the same time one of the most misunderstood and contradictory concepts in marketing. There is still no universal approach to marketing ethics. However, it is an important factor in encouraging marketing decisions that are acceptable to the company as well as being beneficial to society.

Ethics refers to the moral judgment of decisions and actions as correct or incorrect on the basis of generally accepted principles of behavior. In this sense, marketing ethics has moral principles that define the right and wrong marketing behavior. Most basic ethical issues are formalized by laws and regulations, according to the standards of society. But marketing ethics goes beyond legal issues, so ethical marketing decisions encourage mutual understanding between society and businesses. Ethics are individual behaviors and may differ among people. Marketers, although acting on their own behalf, must comply with accepted standards of conduct to guide all marketing decisions. And they should be in accordance with moral principles based on ideals such as honesty, justice and trust.

Consumers typically accept unethical marketing activities such as false advertising, deliberate sale of harmful products, etc. as unacceptable and often refuse to engage in business relationships with people who have such behavior. Therefore, marketing decisions should also be judged by ethical considerations. However, everyone has different ideas about what is ethical and what is not ethical depending on personal ideas and life experience. (1) Vassileva, A., International Business and Globalization, Knigomania, Sofia, 2010.

\section{ETHICS AND MORAL PHILOSOPHY}

Many ethical marketing decisions are taken by groups, not by individuals. These solutions are based on business goals, not on personal goals. Ethical marketing decisions include issues such as:

What is a misleading ad?

What is a personal sale bribe?

What is a false statement about a product?

These and other ethical issues for some people seem clear and easy to solve, but in fact, many years of experience need to be solved to find a way to solve such problems. For example, if the seller's offer to the buyer to take him to a restaurant is a bribe or a good communicative practice to improve sales.

Regardless of how a person or firm considers the acceptability of an activity if society considers it unacceptable or unethical, then 
that view directly affects the ability of the firm to achieve its goals.

In order to understand the importance of ethics in making a marketing decision, it is necessary to explore the factors that influence ethical decision making. Such are: personal moral philosophy; organizational links and opportunities. They are intertwined in determining ethical decisions in marketing. (2) Marinova, N. International Marketing, NBU, Sofia, 2017.

The moral philosophy includes principles or rules that individuals use to define their behavior. They are leading positions for conflict resolution and provide mutual benefit to all members of society. People study these principles and rules through their contacts with family members, social groups, religion and education. Every moral philosophy has its own concept of fairness and ethics and rules of conduct. Two distinctive moral philosophies utilitarianism and ethical formalism - deserve attention. (3) Gebundene, A. Wir sind Chef: Wie eine unsichtbare Revolution Unternehmen verändert (Haufe Fachbuch), nmantis Deeutschland Gmbh, German, 2016.

Utilitarian moral philosophies are aimed at maximizing the greatest good for the largest number of people. Utilitarianists assess an action based on the consequences for all people affected by this action. In a situation with an ethical component, utilitarianists compare all possible options and choose the one that promises the best results. According to them, any action that leads to personal gain at the expense of society as a whole will not be ethical.

Ethical formalism is linked to the development of special rules of conduct that focus on intentions relating to a particular behavior and the rights of the individual. It determines whether a behavior is evaluated as a general rule without showing any interest in alternative results. Behavior is assessed on the basis of violation of individual rights and universal rules. The golden rule of ethical formalism is: "Do for others what you want them to do for you." In marketing, ethical formalism is in line with the idea of consumer choice. For example, users have the right to know about possible defects in a product.

Research has shown that, while moral philosophies and values are involved in business decisions, they are not its central component that determines the decisions, actions, and policies of a firm. This shows why individuals change their moral philosophy between home and work, and why personal values are only part of the company's overall value system.

\section{BUSINESS ETHICS AND MARKETING CONTEXT}

Opportunities are other pressures that can determine whether a person will behave ethically. The opportunity is a favorable set of conditions that put barriers or provide awards. Prizes may be internal or external. Internal rewards are the feelings of kindness and value that one experiences after a noble act. The external awards are what people expect from others in terms of the values generated and provided on a reciprocal basis. They are often received by superiors in the form of praise, rises or salary increases.

Practice shows that if a marketer takes advantage of the possibility of non-ethical behavior and is rewarded rather than punished, he can repeat such action once again. Therefore, the higher the awards and the smaller the penalties for unethical behavior, the greater the likelihood of practicing such behavior.

Developing a sense of ethics is important for understanding marketing ethics. When an activity causes users to feel cheated or manipulated, ethical issues arise, regardless of the legality of this activity. Ethical problems arise from the conflict between marketing efforts to achieve the company's goals and consumer wishes for safe and reliable products.

\section{ETHICAL PROBLEMS AND THEIR SOLUTION}

Regardless of the causes of ethical issues, once identified, marketers and businesses have to decide how to deal with them.

Ethical product-related problems arise when marketers can not expose the risks to the use of the product or can not provide information about its function, value and use. Increasing competition and lowering profits often exacerbate the pressure to replace lower-quality product components to reduce costs. An ethical problem also arises when marketers fail to inform consumers about changes in product quality, which is a form of dishonesty about the essence of the product. (5) Osterwalder, A., Y. Pigneur. Business Model Generation: Ein Handbuch für Visionäre, Spielveränderer und Herausfordere, 2011. 
The communication process provides a variety of situations that can create ethical issues. For example, fake and misleading advertising, manipulative and false promotion of sales,

Ads can range from exaggerated statements and hidden facts to a real lie. Exaggerations can not be proven. If a commercial ad claims that a washing powder is better than any other on the market. This very often can not be confirmed by users or experts. Hidden facts are material facts that are deliberately missed by a single message. But when consumers realize that promotional messages are not true, they feel deceived and refuse to buy the product again or to alert the relevant regulatory bodies.

Another form of advertising misconception is ambiguous statements. For example, the word "helps" is often used in the creative - "helps improve," "helps you feel better", and so on. Some marketers view such messages as acceptable, others do not accept them because they are indefinable and pose an ethical problem.

Ethical issues also arise in the sales process. A vendor may need to tell the customer the truth about the product's defects by risking losing it or in some way misleading the client to sell the good to him. But the second case often has the effect of the "snowball". Once the seller lied to a client, it's getting harder to tell the truth. If the customer learns about fraud, the seller loses not only his trust but also the trust of his friends and colleagues.

Ethical problems in distribution relate to connections between manufacturers and intermediaries, when payments are delayed, when product availability is being manipulated to exert pressure on intermediaries, when illegal copies are distributed, and so on.

\section{UNIFORM ETHICAL CULTURE AND MARKETING ACTIVITY}

Introducing marketers to ethical issues and potential conflict areas makes it possible to eliminate emerging ethical issues in everyday marketing. Ethical values should be embedded in the organizational culture and marketing strategy of the company. Because it is difficult for employees to determine which behavior in a company is acceptable and what is not acceptable, the company has to create uniform rules and standards to describe what is expected of each employee's behavior. (6) Avramov, V., Industry 4.0 - Challenges to Developing and Managing Human, Capital, Authority, Governance and Societal Development, Panayotov, D. (editor), Sofia 2017, pp. 531-539.

\section{CONCLUSION}

In order to preserve socially responsible behavior while pursuing the company's objectives, it is necessary to monitor the changes and trends in the values of society. A few decades ago, cigarette manufacturers freely advertised their use. Years after cigarette smoking has been shown to be linked to cancer and other medical problems, the public's attitudes to smoking have changed and marketers are faced with new social responsibilities - smoking bans and provision of certain places for smoking have begun.

Since society consists of different groups, it is very difficult or even impossible to determine, in some cases, what society wants in general. For example, marketers in attempting to meet the wishes of a group may not satisfy the wishes of another group. In the "for" and "anti" smoking debates, marketers should blaze between smokers 'and non-smokers' desires in defining smoking spots.

Although social responsibility may seem like an abstract ideal, managers take decisions on a daily basis that correspond to social responsibility. These decisions concern first and foremost the rights of consumers who are increasingly bound by the adoption of certain laws.

\section{REFERENCES}

1. Avramov, V., Industry 4.0 - Challenges to Developing and Managing Human, Capital, Authority, governance and societal development (Global, regional and national perspectives), Panayotov, D., (editor), Sofia 2017, pp. 531-539

2. Vasileva, A., International Business and Globalization, Knigomania, Sofia, 2010.

3. Gebundene, A. Wir sind Chef: Wie eine unsichtbare Revolution Unternehmen verändert (Haufe Fachbuch), nmantis Deeutschland Gmbh, German, 2016.

4. Hussey, D. Strategic Management: From Theory to Implementation, Routhledge, UK, 2007.

5. Marinova, N. International Marketing, NBU, Sofia, 2017.

6. Marinova, N. Project Management and Sustainable Development, NBU, Sofia, 2014.

7. Mladenova, G. Marketing Planning, UE "Iconomics", Sofia, 2006.

8. Mercer, D. Marketing Strategy - the Challenges of the External Environment. Penguin Books, Duseldorf, 1998.

9. Osterwalder, A., Y. Pigneur. Business Model Generation: Ein Handbuch für Visionäre, Spielveränderer und Herausfordere, 2011.

10. Schmitz, H. Project controlling, 3. Auflage, Dusseldorf, 1996. 